formulation is useful because it provides an organizational framework for consideration of the variables affecting the behavior. In the present case, for example, the equation implies that there is no change in the slope of the function as $\Delta T_{\text {hy }}$ changes from positive to negative values. This implication is borne out by the experimental results and suggests that hypothalamic sensitivity is equal for both heating and cooling. Whether the same equation will also describe the behavioral responses produced by prolonged displacements of hypothalamic temperature has not been determined in the present experiments, but there is no reason to expect that it should. Experiments where hypothalamic temperature was displaced for periods up to $2 \mathrm{~h}$ indicated that the initial behavioral adjustments of air temperature, so dramatically displayed in the present experiments, tend to be modified over time (Adair et al, in press). The behavior pattern shifts as the total heat content of the animal gradually shifts. This should be expected, after all. Although the monkey in Fig. 1 sometimes chose the $50^{\circ} \mathrm{C}$ air for an entire $10-\mathrm{min}$ period, it is evident that he could not make this choice indefinitely, for this would soon produce severe hyperthermia and death. Therefore, the type of behavioral change depicted in Figs. 1 and 2 represents only a transient phenomenon. It is nonetheless very potent and describes, at least to a first approximation, the control exerted over behavior by neural signals from the hypothalamus.

\section{REFERENCES}

ADAIR, E. R., CASBY, J. U., \& STOLWIJK, J. A. J. Behavioral temperature regulation in the squirrel monkey: Changes induced by shifts in hypothalamic temperature. Journal of Comparative \& Physiological Psychology, in press.

BALDWIN, B. A., \& INGRAM, D. L. The effect of heating and cooling the hypothalamus on behavioral thermoregulation in the pig. Journal of Physiology, 1967, 191, 375-392.

CARLISLE, H. J. Heat intake and hypothalamic temperature during behavioral temperature regulation. Joumal of Comparative \& Physiological Psychology, 1966, 61, 388-397.

CORBIT, J. D. Behavioral regulation of hypothalamic temperature. Science, 1969, 166, 256-257.

CORBIT, J. D. Behavioral regulation of body temperature. In J. D. Hardy (Ed.), Physiological and behavioral temperature regulation. Springfield, Ill: Chas. C Thomas, 1970 , in press.

EMMERS, R., \& AKERT, K. A stereotaxic atlas of the brain of the squirrel monkey (Saimiri Sciureus). Madison: University of Wisconsin Press, 1963.

GALE, C. C., MATHEWS, M., \& YOUNG, J. Behavioral thermoregulatory responses to hypothalamic cooling and warming in baboons. Physiology \& Behavior, 1970, 5, 1-6. HARDY, J. D., HELLON, R. F., \& SUTHERLAND, K. Temperature sensitive neurons in the dog's hypothalamus. Journal of Physiology, London, 1964, 175, 242-253.

MURGATROYD, D., \& HARDY, J. D. Central and peripheral temperatures in behavioral thermoregulation of the rat. In J. D. Hardy (Ed.), Physiological and behavioral temperature regulation. Springfield, 111: Chas. C Thomas, 1970 , in press.

NAKAYAMA, T., HAMMEL, H. T., HARDY, J. D., \& EISENMAN, J. S. Thermal stimulation of electrical activity of single units in the preoptic region. American Journal of Physiology, 1963, 204, 1122-1126.

SATINOFF, E. Behavioral thermoregulation in response to local cooling of the rat brain. American Journal of Physiology, 1964, 206, 1389-1394.

SMITH, P. E., \& JAMES, E. W. II. Human responses to heat stress. Archives of Environmental Health, 1964, 9, 332-342.

STOLWIJK, J. A. J., \& HARDY, J. D Temperature regulation in man-A theoretical study. Pflügers Archiv, 1966, 291, 129-162.

\section{NOTES}

1. This research was supported by USPHS Grant ES00354-02. The technical assistance of Miss Ruth Harildstad is gratefully acknowledged. A portion of the results was presented to the Psychonomic Society, St. Louis, 1969. Address reprint requests to Eleanor R. Adair, John B. Pierce Foundation, 290 Congress Avenue, New Haven, Conn. 06519.

2. The data acquisition system was designed and instrumented by Mr. James U. Casby of the John B. Pierce Foundation Laboratory.

\title{
The relationship of acid-soluble nitrogen in rat brain to avoidance behavior
}

\author{
MARTIN GOLD, MARK MILLER, HENRY ALTSCHULER, \\ MORTON H. KLEBAN, and M. POWELL LAWTON \\ Gerontological Research Institute \\ Philadelphia Geriatric Center, Philadelphia, Pa. 19141
}

A limited avoidance training schedule was used to train albino Wistar rats. The rats were sacrificed immediately after training. Rats with no training were used as a control group. Acid-soluble nitrogen was measured in three brain sections (cerebrum, brain stem, and cerebellum). Each brain section exhibited an increase in acid-soluble nitrogen with training, suggesting that the increase was due to an enlargement of the amino acid pool.

In two previous reports from our laboratory (Gold et al, 1969, 1970) nonprotein nitrogen (NPN) was estimated by subtracting the contribution of protein nitrogen, by assuming the nitrogen content to be $16 \%$. The first report (Gold et al, 1969) showed that the calculated NPN value was significantly depressed $2 \mathrm{~h}$ after escape training, but not immediately after termination of the training. Since the protein concentration rose as the NPN plummeted, it was speculated that this drop could reflect utilization of amino acids for protein synthesis. A second report (Gold et al, 1970) studied the relationships among the cerebellum, brain stem, and cerebrum with respect to control, avoidance, and avoidance-plus-extinction behavior for total nitrogen and estimated NPN. Significant differences in NPN were found for the brain sections, and aged animals had higher concentrations of NPN than the young in the avoidance-plusextinction training condition. Those values were significantly correlated with extinction behavior in the aged but not in the young rats.

This report represents studies that were carried out to ascertain if the results noted for the calculated NPN would still be obtained with direct chemical analysis of acid-soluble nitrogen. Trichloracetic acid was used to precipitate the protein and nucleic acid in three brain sections (cerebrum, brain stem, cerebellum) and the acid-soluble nitrogen determined. A control group and an avoidance-trained group were analyzed.

\section{METHOD}

The experimental apparatus was a 30-in.-long automated straight runway maze. By rotation of the endboxes, acting alternately as start- and goalboxes, around a stationary stem, animals could receive aversive training without handling between trials. It was a massed training procedure, the time between any two trials being $16 \mathrm{sec}$. The Es will supply a detailed description of the apparatus and methodology upon request.

Twenty-four albino Wistar rats were used. Twelve were assigned to a control group that received no training. Twelve rats received limited avoidance training that consisted of 20 trials. On each trial, the animal was given a $1.0-\mathrm{mA}$ electric shock, but the $S$ could, by running, avoid most of the punishment. Immediately upon 
Table 1

Acid-Soluble Nitrogen Levels for Albino Rats Sacrificed Immediately After Avoidance Training ( $\mathrm{mg} \mathrm{Nitrogen} / \mathrm{g}$ of Wet Tissue Weiglit)

\begin{tabular}{|c|c|c|c|c|c|c|c|}
\hline \multirow{2}{*}{$\begin{array}{c}\text { Brain } \\
\text { Section }\end{array}$} & \multicolumn{2}{|c|}{ Avoidance Training Group } & \multicolumn{2}{|c|}{ Control Group } & \multirow[b]{2}{*}{ t Ratio } & \multirow[b]{2}{*}{ df } & \multirow[b]{2}{*}{$\mathrm{p}$} \\
\hline & Mean & $\sigma \mathrm{M}$ & Mean & $\sigma \mathrm{M}$ & & & \\
\hline Cerebrum & 2.31 & .03 & 2.11 & .02 & 3.76 & 22 & $<.01$ \\
\hline Brain Stem & 2.40 & .05 & 2.11 & .03 & 4.73 & 22 & $<.01$ \\
\hline Cerebellum & 2.27 & .03 & 2.06 & .04 & 3.74 & 22 & $<.01$ \\
\hline
\end{tabular}

termination of the training, the rats were decapitated and the brains removed.

The three brain sections were isolated and homogenized in $15 \%$ trichloracetic acid (TCA), the mixture centrifuged, the precipitate washed twice with two volumes of TCA, and the washings pooled. The nitrogen content was determined by the Kjeldahl procedure as modified by Koch $\&$ McMeekin (1924) and designated "acid-soluble nitrogen (ASN)." The results were expressed as $\mathrm{mg}$ nitrogen $/ \mathrm{g}$ of wet tissue weight.

\section{RESULTS}

The data were statistically analyzed by a L in d quist (1953) Type I analysis-of-variance design. An $F$ ratio of $32.66(\mathrm{df}=1 / 22, \mathrm{p}<.001)$ was found between the avoidance trained (total arithmetic mean $=2.33$ ) and the untrained control (total arithmetic mean $=2.09$ ) group. The $t$ ratios by brain sections are presented in Table 1. The avoidance training groups evidenced significantly higher means than the controls in each of the brain sections.

An $F$ ratio of $4.00(\mathrm{df}=2 / 44, \mathrm{p}<.05)$ indicates a significant difference among the brain sections. The brain stem $(M=2.26)$ appeared significantly greater than the cerebellum $\left(\mathrm{M}=2.17, \mathrm{M}_{\mathrm{D}}=.09, \mathrm{p}<.01\right)$. Although this main effect was significant, the Treatment by Subjects analysis of variances for the avoidance training and untrained controls was not significant. brain to be about $0.06 \mathrm{mg} / \mathrm{g}$ wet weight of tissue. If the increase noted after training was due solely to amino acid nitrogen, the pool would have quadrupled in size. This would be equivalent to $1.5 \mathrm{mg}$ of protein $/ \mathrm{g}$ wet tissue. In the aforementioned study (Gold et al, 1969), the protein increase, above that of the rats immediately killed after training, was about $2.5 \mathrm{mg} / \mathrm{g}$ wet weight after $2 \mathrm{~h}$.

The cerebellar content of total nitrogen and calculated NPN (Gold, 1970) as well as ASN was the lowest of the three sections in control rat brains. Since the cerebellar response to training was not evoked as strongly as the cerebrum and brain stem, the constituents in this nitrogen pool may play an important role in the final chemical expression caused by the training stimulus.

\section{REFERENCES}

AGRAWAL, H. C., DAVIS, J. M., \& HIMWICH, W. A. Postnatal changes in free amino acid pool of rat brain. Journal of Neurochemistry, 1966, 13, 607-615.

GOLD, M., ALTSCHULER, H., KLEBAN, M. H., LAWTON, M. P., \& MILLER, M. Chemical changes in the rat brain following escape training. Psychonomic Science, 1969, 17, 37-38.

GOLD, M., KLEBAN, M. H., ALTSCHULER, H., LAWTON, M. P., \& MILLER, M. The relationships of non-protein nitrogen and total nitrogen in rat brain to avoidance extinction behavior. Psychonomic Science, 1970, 20, 41-42.

KOCH, F. C., \& MCMEEKIN, T. L. A new direct Nesslerization micro-Kjeldahl method and a modification of the Nessler-Folin reagent for ammonia. Journal of the American Chemical Society, 1924, 46, 2066-2069.

LINDQUIST, E. F. Design and analysis of experiments in psychology and education. New York: Houghton Mifflin, 1953. 